\title{
Pedestrian Infrastructure Quality of Service In Urban Neighborhood: A Case Study in Wangsa Maju, Kuala Lumpur, Malaysia
}

\author{
Ida Shaheera Bakhtiar*, Safizahanin Mokhtar, Muhammad Zaly Shah Hussein \\ Department of Urban and Regional Planning, Faculty of Built Environment and Surveing, Universiti Teknologi Malaysia, \\ Johor Bahru, Malaysia \\ *Correspondence: idasheera@gmail.com
}

SUBMITTED: 15 December 2021; REVISED: 26 January 2022; ACCEPTED: 29 January 2022

\begin{abstract}
The effectiveness of security and accessibility to all facilities supplied in the neighborhood area was evaluated using the Pedestrian Infrastructure Quality of Service methodology. The method is known as a "mix of land uses to test pedestrian connectivity," and it encompasses land use and connectivity within a 400-meter walking radius, as indicated on the map. According to the findings, $28 \%$ of pedestrians in the age range of 25-34 years old were eager to walk in a neighborhood with good pedestrian infrastructure and a safe environment for walking. The elderly were less willing to walk because of the lack of pedestrian infrastructure, which prevented people from using walking as a mode of transportation. Professionals, who accounted for $45.6 \%$ of all responses, favored increased provision for pedestrians in the neighborhood area to encourage more people to walk instead of driving private vehicles.
\end{abstract}

KEYWORDS: Pedestrian infrastructure; pedestrian; neighborhood area; Wangsa Maju

\section{Introduction}

The terms "walkable" and "neighborhood" imply a walkable neighborhood. The meaning of "walkable" is that an area is also defined as a place that is suitable, safe, and capable of being reached by walking. Walkability can actually be the focus of many conditions or can express which walking areas are allowed, including areas that are conveyable, compact, physically enticing, or safe [1]. Meanwhile, "neighborhood" refers to a physical concept that covers the area in which residents share the same services, social activities, and facilities provided in the surrounding area of their dwelling. The Macquarie Dictionary broadly defines a neighborhood area as one that provides facilities for people to shop, engage in recreational activities, and carry out other daily routines within walking distance. Residents refer to such an area as a "walkable neighborhood" [2]. The study on the walkability of an area is relevant to determining the friendliness of a city in terms of walking [3]. Abley (2005) referred to walkability as "the scope where the built environment is friendly for the presence of people living, shopping, visiting, enjoying or spending time in an area" [4]. 
Walking can bring social benefits by increasing neighborhood interaction and community cohesion, as well as improving the opportunity to preserve cultural resources and the aesthetic of an area. Likewise, walking can be beneficial to the environment by reducing the use of land for roads and parking facilities and reducing energy consumption and pollution [3]. Azmi and Karim's study of walkability in Malaysia found that walking distances of fewer than 200 meters were still walkable before Malaysians chose to commute by vehicle. However, as stated by Clarence Perry's walking distance standards, 400 meters is not fit to be used in equatorial climate countries such as Malaysia [4].

Apart from that, Malaysia aims to make the city center a transit-oriented city, since currently there is a heavy dependence on private vehicles as the primary transportation mode instead of walking [5]. According to the Malaysian Automotive Association (2018), the total number of registered vehicles had increased by $2.1 \%$, with 261,043 vehicles sold in the year 2018 as compared to the year 2017 with only 255,748 [6]. This upsurge is due to the reduction in prices after the government announced a GST tax holiday for three months, as well as attractive Hari Raya promotions and offers by Malaysian Automotive Association (MAA) members, which have created a soaring demand for vehicles in Malaysia. Furthermore, the design of Kuala Lumpur, the capital city of Malaysia, is inconvenient to walk in, which makes it a challenge for pedestrians to walk in the city [7]. In addition, 59\% of people in Kuala Lumpur admitted that they disliked commuting along with other users of public transportation such as on the Light Railway Transit (LRT) and other public transport, which caused them to drive their own vehicles, as they could stay more comfortable and safer at all times [8]. Currently, the non-triggers of walking in Malaysia are becoming crucial.

Furthermore, previous study suggested the idea of urban sustainability by considering walking as the best way to promote sustainability as well as improve the livability of the urban context. Walking and cycling are identified as the healthiest and most sustainable modes of transport [2]. Another study showed that people who lived in highly walkable neighborhoods spent more time walking per week on average than people living in low-walkable neighborhoods [8]. However, previous study stated that a variety of land-uses, a grid-pattern street layout, higher residential density, a perceived sense of safety, closeness to public transportation, environmental features area, neighborhood amenities, and the existence of walking facilities have all been linked to increased walking behavior [9]. Pedestrians account for approximately $15 \%$ to $20 \%$ of road accident deaths in developed countries and $40 \%$ to $50 \%$ of road deaths in developing countries [3]. Therefore, in this study, the first aim is to identify the deficiency of pedestrian infrastructure in Wangsa Maju towards creating a walkable neighborhood. Meanwhile, the second aim is to determine the frequency of walking and the reasons behind the unwillingness of Wangsa Maju residents to walk in a radius of 400 meters.

\section{Materials and Methods}

Walking plays a vital role in social benefits. Walking is also the most basic form of transportation [3]. Walkability is measured by the friendliness of an area in terms of the possibility for pedestrians to willingly walk there. Therefore, better provision of pedestrian infrastructure in an urban neighborhood area can create a vibrant pedestrian street life. Walking in the neighborhood is defined as a place within easy walking distance, like 10-15 minutes' walking time from one's residence. The benefits of walking are found in the aspects of health, economy, and communication [10]. The land use of an area should be attractive to entice people 
to willingly walk. Other aspects include the affordability of commuting from one place to another and the provision of a better road network, all of which can encourage people to willingly walk in a highly walkable area [11].

\subsection{Taking a stroll around the neighborhood}

Walking is a physically demanding activity. Pedestrians should be able to walk with safety and convenience in order to encourage them to do so. A neighborhood area with suitable walking conditions can encourage them to walk more often. The features that can turn a neighborhood into a more walkable area are accessibility, convenience, attractiveness, road safety, and personal safety [12]. Another characteristic is enhancing the provision of facilities with a physical environment that can influence people to walk [4]. There are benefits to walking in terms of social interest. A walking neighborhood can be developed when the social benefits of walking are able to increase neighborhood interaction and community cohesion for the residents [3].

Therefore, walking behavior influences people to walk in the neighborhood area. According to previous study, individuals who have a firm action orientation can devote cognitive resources to the task given, enabling them to convert their intention into behavior efficiently [8]. Meanwhile, previous scholars mentioned that an individual's response to walking is due to the relationship between walkability and built environments. By transforming cities into more walkable areas, the emphasis should be on making the area comfortable to walk in, safe, interesting, and convenient, while explicitly connecting one place to another [12]. Walking behavior measurements, such as walking distance, walking time, and walking speed, which are related to the analysis of walking behavior, can be used. Usually, a person can walk within a certain distance of 400 meters, which is almost 5 minutes of walking [13]. At a range of 400 meters, this is a reasonable walking distance for people to walk at a certain time [14]. For the elderly and preschoolers, the maximum and most convenient distance that can be achieved by them is 190 meters [5].

Meanwhile, for primary school children, the distance is between 191 meters and 380 meters. As for teenagers and adults, they can achieve 600 meters. Furthermore, a maximum distance of $200 \mathrm{~m}$ or less is reachable for walking only to reach their community facilities from their houses before they switch to driving their vehicles $[4,5,15]$. The arguments can be seen from Clarence Perry's statement that the 400-metre maximum walking distance is not a suitable distance to commute in a neighborhood area [15]. This means that a nearer destination for pedestrians to move from one place to another can provide users with a shorter range to reach a closer journey [16].

\subsection{Site Visit}

The site visit was held in Wangsa Maju, where the specific road at Jalan 2/27A was chosen. This site was selected because there were various community facilities available in the residential area. This site visit was carried out to observe and evaluate the level of preparation and problem-solving of pedestrian infrastructure in Wangsa Maju. Kuala Lumpur City Hall is the authority for this study. 


\subsection{Interview}

The interview was held for four (4) days from July $18^{\text {th }}$ until July 21 st, 2018 at the study site. This interview was conducted with 103 respondents selected based on a simple random sampling method. The interview was held to obtain feedback and share experiences, knowledge, and information. Then, the responses were tabulated and analyzed with a chisquare test using the Statistical Package for the Social Sciences (SPSS) software.

\section{Results and Discussion}

This paper aimed to assess the deficiency of pedestrian infrastructure on walkability in a neighborhood area. This research paper was conducted to assess a suitable variable to be used in the study. The area of Jalan 2/27A in Wangsa Maju, Kuala Lumpur was selected as a sample of urban neighborhood areas for the research. Wangsa Maju is one of the largest townships in Kuala Lumpur and is located $6.5 \mathrm{~km}$ north of Kuala Lumpur. A total of 103 respondents who lived at Jalan 2/27A were randomly selected to answer the questionnaire survey. The respondents were 44 males $(42.7 \%)$ and 59 females $(57.3 \%)$. The sample size is considered ample and adequate for this study. Previous study mentioned that the sample size should be an adequate amount because it will provide the necessary information to explain the characteristics of the entire population [17]. This methodology has already obtained approval from each Pihak Berkuasa Tempatan (PBT), which is known as the local government authority, and other related resources. Another research instrument for this study included a site visit, a review of journals and books, desktop studies, and interviews.

\subsection{PIQOS tools}

A Pedestrian Infrastructure Quality of Service (PIQOS) model was used to assess the problems with the neighborhood's pedestrian infrastructure. PIQOS used a rubric as the tool to assess the issues in the study area. This rubric explains the quality-of-service components with descriptions of certain marks. The quality of service components was divided into ten (10) main components, which are formal (paved and continuity), curb1 (height, in which the standard is $150 \mathrm{~mm} / 6 \mathrm{in}$.), curb2 (marking), barrier 1 (physical), barrier 2 (buffer zone [Std. 0.6 $\mathrm{m} / 2 \mathrm{ft}$. wide]), universality 1 (width $\mathrm{Std} .1 .5 \mathrm{~m}$ ), universality 2 (which is tactile paving), comfort 1 (which is free of obstructions (FOO), comfort 2 (which is about evenness in terms of unevenness along the entire segment surface of the walkway), and comfortability 3 (which is about traction). The grading of PIQOS will be evaluated according to the marks that count. The marks can then be used to identify the quality of the pedestrian pathways.

The quality of pedestrian infrastructure can be differentiated by different colors. Blue is the quality for grades A and A-, which means that the pedestrian area is a complete street, in which it is relaxed, pleasant, and enjoyable for a pedestrian to walk. Meanwhile, for grade A-, the pedestrian walkways are comfortable and relaxed for a pedestrian to walk, but still in blue. The quality color for grades B and B-is green, which represents a pedestrian-friendly walkway. The meaning for grades B and B-is that the pedestrian walkway is safe and secure for pedestrians to walk on and has ample evidence of efforts to protect pedestrians. Yellow is the quality for grades $\mathrm{C}$ and $\mathrm{C}$-, which means to exercise caution. This shows that the pedestrian walkway is an excellent attempt to protect pedestrians. 
Meanwhile, for grade $\mathrm{C}$, the pedestrian walkway meets the minimum requirements to protect pedestrians. The quality color for grades D and D-is orange, which means risky. The meaning of grade $\mathrm{D}$ is that the pedestrian walkway has minor evidence of attempts to protect pedestrians, while grade D-has marginal attempts to protect pedestrians. The quality for grades E and E-is red, which means dangerous. Grade E indicates that the pedestrian walkway has inadequate pedestrian protection in most segments of the streets. However, for grade $\mathrm{E}$, the pedestrian walkways scarcely have any evidence of pedestrian protection. Grade $\mathrm{F}$ is considered the worst for pedestrian walkways. Grade $\mathrm{F}$ is in the black quality, which is also known as a hotspot. This improper pedestrian infrastructure means that the pedestrian walkway is a complete failure to protect pedestrians, which is also known as an unacceptable condition (Table 1).

Table 1. Colour of quality and its meaning for pedestrian infrastructure using PIQOS.

\begin{tabular}{|c|c|c|c|c|c|}
\hline Grade & Marks & $\begin{array}{l}\text { Cut- } \\
\text { off } / 50\end{array}$ & Code & Meaning & Quality \\
\hline A & $9.50-10.0$ & 47.50 & $\mathrm{~A}+$ & $\begin{array}{l}\text { Relaxed, pleasant, and enjoyable for } \\
\text { pedestrians to walk }\end{array}$ & \multirow{2}{*}{$\begin{array}{l}\text { Complete } \\
\text { street }\end{array}$} \\
\hline A- & $8.50-9.49$ & 42.50 & A9 & $\begin{array}{l}\text { Comfortable and easy for pedestrians to } \\
\text { walk }\end{array}$ & \\
\hline B & $7.50-8.49$ & 37.50 & B8 & Safe and secure for pedestrians to walk & \multirow[b]{2}{*}{$\begin{array}{l}\text { Pedestrian- } \\
\text { friendly }\end{array}$} \\
\hline B- & $6.50-7.49$ & 32.50 & B7 & $\begin{array}{l}\text { Ample evidence of efforts to protect } \\
\text { pedestrians }\end{array}$ & \\
\hline $\mathrm{C}$ & $5.50-6.49$ & 27.50 & C6 & Good attempt to protect pedestrians & \multirow{2}{*}{$\begin{array}{l}\text { Exercise } \\
\text { caution }\end{array}$} \\
\hline $\mathrm{C}-$ & $4.50-5.49$ & 22.50 & $\mathrm{C} 5$ & $\begin{array}{l}\text { Meeting minimum requirements to } \\
\text { protect pedestrians }\end{array}$ & \\
\hline $\mathrm{D}$ & $3.50-4.49$ & 17.50 & D4 & $\begin{array}{l}\text { Minor evidence of attempts to protect } \\
\text { pedestrians }\end{array}$ & \multirow{2}{*}{ Risky } \\
\hline D- & $2.50-3.49$ & 12.50 & D3 & Marginal attempts to protect pedestrians & \\
\hline $\mathrm{E}$ & $1.50-2.49$ & 7.50 & E2 & $\begin{array}{l}\text { Inadequate pedestrian protection in most } \\
\text { segments of the streets }\end{array}$ & \\
\hline E- & $0.50-1.49$ & 2.50 & E1 & $\begin{array}{l}\text { Scarcely any evidence of pedestrian } \\
\text { protection }\end{array}$ & \\
\hline $\mathrm{F}$ & $0-0.40$ & 0 & F0 & $\begin{array}{l}\text { Complete failure to protect pedestrians. } \\
\text { Unacceptable condition. }\end{array}$ & Hotspot \\
\hline
\end{tabular}

\subsection{The study area of neighborhoods in Wangsa Maju}

The neighborhood area in Wangsa Maju is surrounded by various developments and facilities for the residents. Figure 2. The dwellings, shops, religious areas, recreation parks, schools, and utilities within a 400-metre radius of Wangs Maju are shown in Figure 2. The study was conducted in an urban area at Jalan 2/27A in Wangsa Maju. Wangsa Maju is one of the largest townships in Kuala Lumpur and is located $6.5 \mathrm{~km}$ north of Kuala Lumpur. The mix of land uses creates a diversity of access to facilities for the residents. Residential density and the connectivity of the streets make it a more fundamental aspect of creating more walkable areas [3]. 


\subsection{Pedestrian infrastructure in Wangsa Maju}

Pedestrian infrastructure is provided for the convenience of pedestrians. This provision aims to make the pedestrians happy and safe when they walk in that area. The pedestrian infrastructure in Wangsa Maju is already provided in a master plan of Wangsa Maju. The provision of pedestrian infrastructure was a massive development. However, based on the on-site visit observation, there was still a deficiency of pedestrian infrastructure that needed to be improved to create a better walking environment in Wangsa Maju.

\subsection{The frequency of walking}

The Chi-square for each item was also analyzed to indicate the value for each attribute, which included the frequency of walking and the reason not to walk. There are five (5) different periods for the frequency of walking. The finding showed that the Pearson's chi-square value for the frequency of walking is $2.073 \mathrm{a}$ with two (2) cells. $20.0 \%$ expected a count of less than five, in which the minimum estimated count is 3.42 for walkers. There were 11 males who walked on a daily basis as compared to 10 females. On the other hand, females were found to be the top walkers with 20 walkers in the period of 2-3 days a week, while there were only 11 male walkers, as most males used their own vehicle, like a car or motorcycle, to commute in the neighborhood area. The convenience of walking demonstrated that walking in Jalan 27/2A was mostly dominated by females because of their proximity to places of work, convenience, and accessibility (Table 2). People who rarely walk tend to use vehicles for the reason that the weather discourages them from walking. According to [4], when the weather conditions are scorching hot during the day, it can limit a person's movement, especially in tropical Malaysia.

Table 2. Frequency of walking in different periods.

\begin{tabular}{lccccccc}
\hline Gender & \multicolumn{7}{c}{ Frequency of walking } \\
& Never & Daily & $\begin{array}{c}\mathbf{2 - 3} \text { days a } \\
\text { week }\end{array}$ & $\begin{array}{c}\mathbf{4 - 5} \text { days } \\
\text { a week }\end{array}$ & $\begin{array}{c}\text { 1 day a } \\
\text { week }\end{array}$ & Total & Pearson chi-square \\
\hline Male & 4 & 11 & 11 & 9 & 9 & 44 & \multirow{2}{*}{$2.073 \mathrm{a}$} \\
Female & 4 & 10 & 20 & 15 & 10 & 59 & \\
\hline Total & $\mathbf{8}$ & $\mathbf{2 1}$ & $\mathbf{3 1}$ & $\mathbf{2 4}$ & $\mathbf{1 9}$ & $\mathbf{1 0 3}$ & \\
\hline
\end{tabular}

Figure 1 show the housing area, or community neighborhood area. The pedestrian walkways graded as D had minor evidence of attempts to protect pedestrians. Grade D is under the quality category of being too risky for pedestrians to walk. Apart from that, to be specific, on one side, the walkway was free of obstructions (FOO) along the entire segment. On the other hand, there were only minor impediments on the opposite side.

Figure 2 and 3 showed a location near the school and neighborhood area, were under grade $\mathrm{F}$, which indicated the areas as hotspots because they had completely failed to protect pedestrians. This is an unacceptable condition. The areas were unpaved, in which there was no walkway or only trails along the entire segment on both sides. Curb 1 indicated the height, which was not applicable as there was no paved walkway. Curb 2 was not applicable. Barrier 1, barrier 2 (the buffer zone), and universality 2 (tactile paving) were irrelevant. Comfort 1 (free of obstructions (FOO)) was also improper. Comfort 2 (evenness) was not applicable, and comfort 3 (tractions) was also not suitable along the entire segment on both sides. 


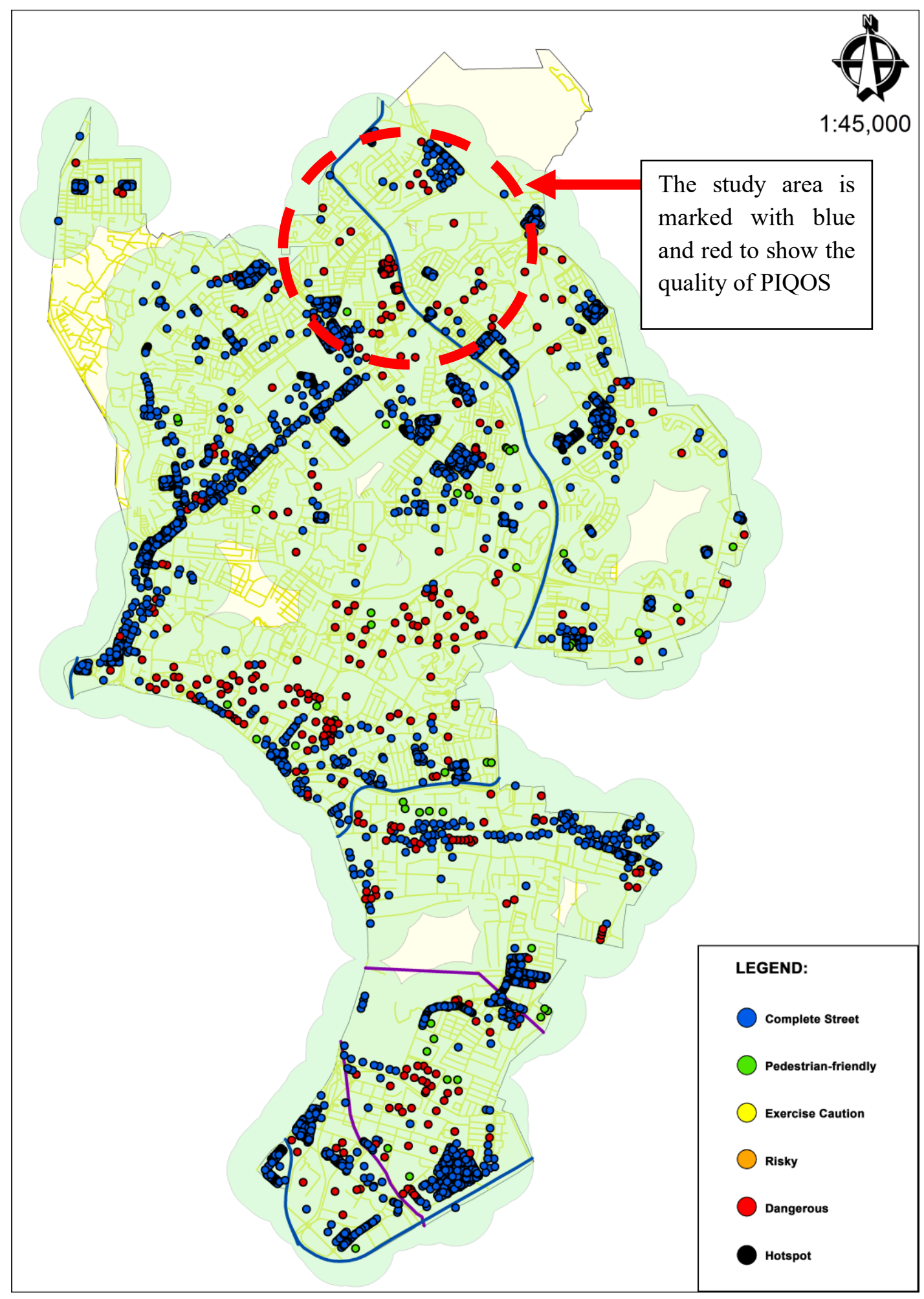

Figure 1. The colour of the quality of pedestrian areas in Wangsa Maju, Malaysia. 


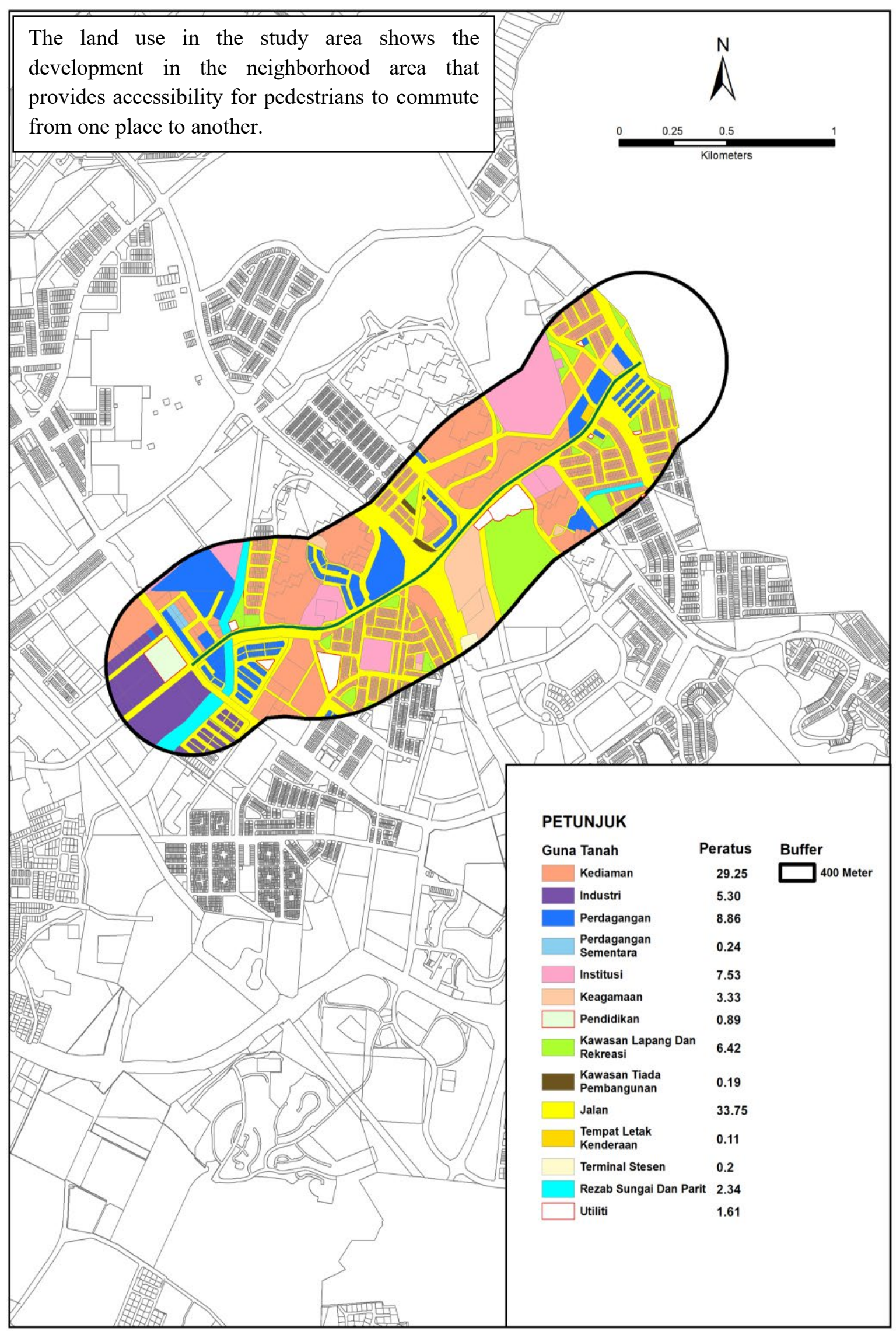

Figure 2. The categories of land use in the study area. 


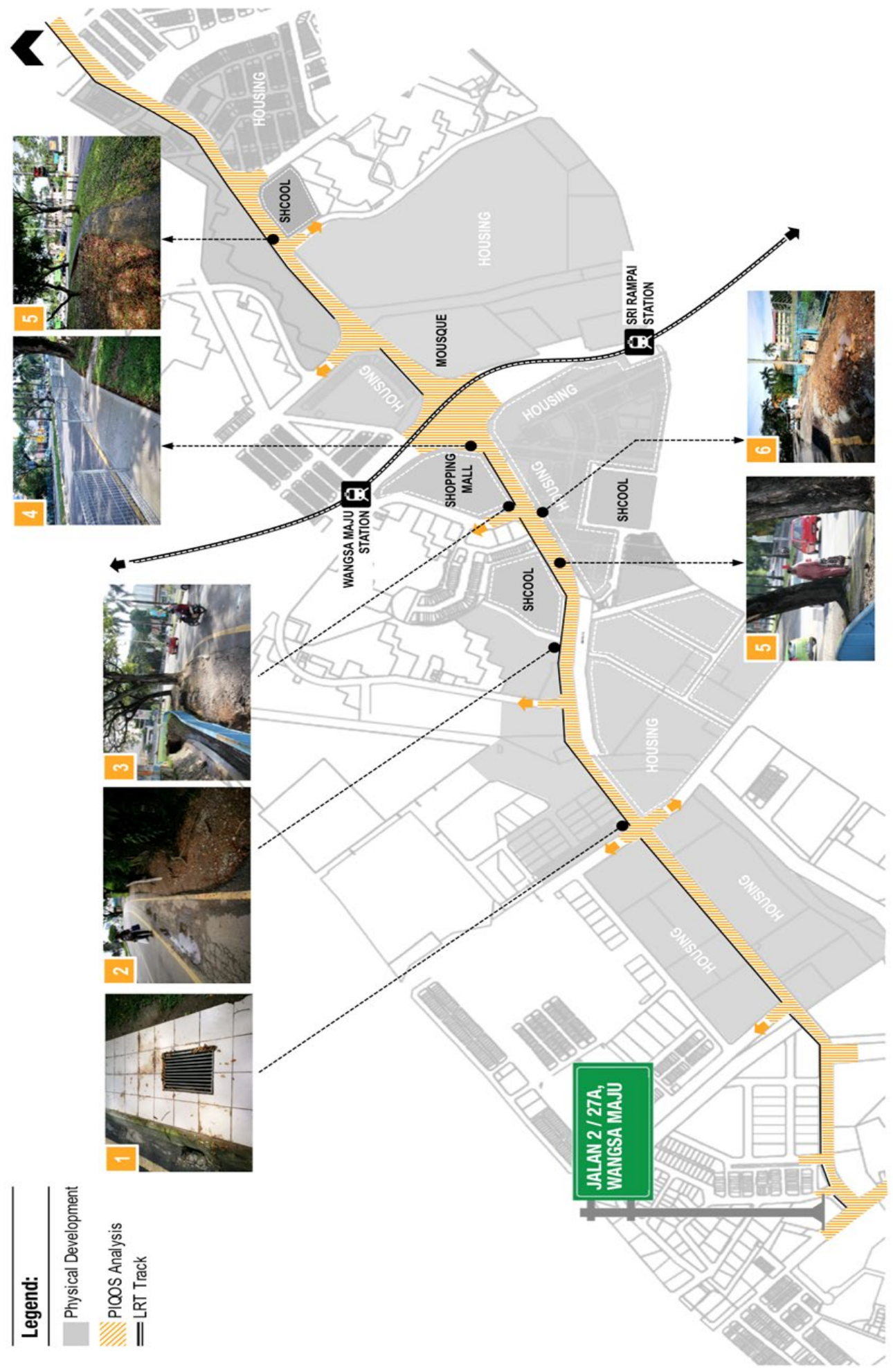

Figure 3. The deficiencies in the study area.

\subsection{Reason for not to walk}

There are a total of four reasons not to walk. The finding used Pearson's chi-square analysis in SPSS to gauge the neighborhood surroundings because Pearson's chi-square analysis is suitable for this study. The result showed that the Pearson's chi-square value for the frequency of walking is $3.507^{\mathrm{a}}$ with three (3) cells. $37.5 \%$ expected a count of less than five (5), in which the minimum expected count is 2.99 for walkers that have a reason not to walk in Table 3 . Even though walking is a proper mode of transport that is mostly accessible [3], weather conditions 
also play a vital role in affecting walking. Residents prefer to walk differently depending on the weather [3].

Table 3. Reasons for not to walk.

\begin{tabular}{cccccccc}
\hline Gender & $\begin{array}{c}\text { Hot } \\
\text { weather }\end{array}$ & Tiredness & $\begin{array}{c}\text { Safety } \\
\text { aspect }\end{array}$ & $\begin{array}{c}\text { Easier to } \\
\text { drive a } \\
\text { car }\end{array}$ & Total & $\begin{array}{c}\text { Pearson's } \\
\text { Chi- } \\
\text { square }\end{array}$ \\
\hline Male & 7 & 1 & 4 & 32 & 44 & $3.507^{\text {a }}$ \\
Female & 13 & 6 & 5 & 35 & 59 & \\
\hline Total & $\mathbf{2 0}$ & $\mathbf{7}$ & $\mathbf{9}$ & $\mathbf{6 7}$ & $\mathbf{1 0 3}$ & \\
\hline
\end{tabular}

\section{Conclusions}

The pedestrian infrastructure in the urban neighborhood of Wangsa Maju needs to be improvised for better liveability and sustainability for the pedestrians and residents in the area. Safety and attractive aspects are crucial to providing a safe walking environment for the pursuit of walking in the Wangsa Maju neighborhood area. The safety and attractiveness of a neighborhood area can provide valid reasons for pedestrians to walk more often without depending on private vehicles. The strategy is to improve pedestrian safety through a better design of sidewalks and related facilities. The focus of this research was to create a tool for evaluating pedestrian infrastructure in neighborhoods using a safety concept. To assess, a review of selected case study topics was selected. The researcher believes that the issues raised in this paper are extremely important and that the findings are strong but not conclusive. However, alternative modes of transportation, such as bicycle lanes, would be extremely beneficial. As a result, this study recommends combining the proposed tool with existing walkability measures in order to get more accurate results regarding the pedestrian infrastructure in neighborhoods. Furthermore, this tool can be developed as software for use by professionals at all levels in urban and transportation planning, as well as public health. This concept can be used in both urban and rural settings.

\section{Acknowledgements}

The authors thank Universiti Teknologi Malaysia for facilitating this work.

\section{Conflicts of Interest}

The authors declare no conflict of interest.

\section{References}

[1] Forsyth, A.; Hearst, M.; Oakes, J.M.; Schmitz, K.H.; Forsyth, A.N.N.; Al, E.T. (2008). Design and Destinations : Factors Influencing Walking and Total Physical Activity. Urban Studies, 45, 1973-1996. https://doi.org/10.1177/0042098008093386.

[2] Amoroso, S.; Castelluccio, F.; Maritano, L. (2012). Indicators for sustainable pedestrian mobility. WIT Transactions on the Built Environment, 128, 173-185. https://doi.org/10.2495/UT120161.

[3] Ariffin, R.N.R.; Zahari, R. K. (2013). Perceptions of the Urban Walking Environments. ProcediaSocial and Behavioral Sciences, 105, 589-597. https://doi.org/10.1016/j.sbspro.2013.11.062.

[4] Azmi, D.I.; Karim, H.A. (2012). Implications of Walkability Towards Promoting Sustainable Urban Neighbourhood. Procedia-Social and Behavioral Sciences, 50, 204-213. https://doi.org/10.1016/j.sbspro.2012.08.028. 
[5] Shamsuddin, S.; Hassan, N.R.A.; Bilyamin, S.F.I. (2012). Walkable Environment in Increasing the Liveability of a City. Procedia - Social and Behavioral Sciences, 50, 167-178. https://doi.org/10.1016/j.sbspro.2012.08.025.

[6] Ministry of Transport Malaysia: Road Accidents and Fatalities in Malaysia. (accessed on 15 July 2019) Available online: www..mot.gov.my/en/land/safety/road-accident-and-facilities.

[7] Malaysian Automotive Association. (accessed on 15 July 2019) Available online: Market_Review_First_Half_2018.pdf.

[8] Shamsuddin, S.; Abu, R.; Ilani, S.F. (2012). Walkable Environment in Increasing the Liveability of a City. Procedia-Social and Behavioral Sciences, 50, 167-178. https://doi.org/10.1016/j.sbspro.2012.08.025.

[9] Friederichs, S.A.H.; Kremers, S.P.J.; Lechner, L.; De Vries, N.K. (2013). Neighborhood Walkability and Walking Behavior: The Moderating Role of Action Orientation. Journal Physical Activity and Health, 10, 515-522. https://doi.org/10.1123/jpah.10.4.515.

[10] Dean, J.; Biglieri, S.; Drescher, M.; Garnett, A.; Glover, T.; Casello, J. (2020). Thinking relationally about built environments and walkability: A study of adult walking behavior in $\begin{array}{llllll}\text { Waterloo, } \quad \text { Ontario. Health } & 02352 .\end{array}$ https://doi.org/10.1016/j.healthplace.2020.102352.

[11] Talen, E.; Koschinsky, J. (2017). The Walkable Neighborhood: A Literature Review. International Journal of Sustainable Land Use and urban Planning, 1, 42-63. http://dx.doi.org/10.24102/ijslup.v1i1.211.

[12] Galanis, A.; Eliou, N. (2011). Evaluation of the pedestrian infrastructure using walkability indicators. WSEAS Transactions on Environment and Development, 7, 385-394.

[13] Rafiemanzelat, R.; Emadi, M.I.; Kamali, A.J. (2017). City sustainability: the influence of walkability on built environments. Transportation Research Procedia, 24, 97-104. https://doi.org/10.1016/j.trpro.2017.05.074.

[14] Azmi, D.I.; Karim, H.A.; Amin, M.Z.M. (2012). Comparing the Walking Behaviour between Urban and Rural Residents. Procedia-Social and Behavioral Sciences, 68, 406-416. https://doi.org/10.1016/j.sbspro.2012.12.237.

[15] Li, J.; Gao, Y.; Yin, H. (2013). Pedestrian Facilities Planning on Tianjin New Area Program. $\begin{array}{llll}\text { Procedia-Social and Behavioral 683-692. } & \text { Sciences, 96, }\end{array}$ https://doi.org/10.1016/j.sbspro.2013.08.079.

[16] Inani, D.; Abdul, H.; Zamreen, M.; Amin, M. (2012). Comparing the Walking Behaviour between Urban and Rural Residents. Procedia-Social and Behavioral Sciences, 68, 406-416. https://doi.org/10.1016/j.sbspro.2012.12.237.

[17] Speck, J. (2013). Walkable City; North Point Press: Barkeley, USA.

[18] Chuan, C.L. (2006). Sample size estimation using Krejcie and Morgan and Cohen stastistical power analysis: a comparison. Jurnal Penyelidikan IPBL, 7, 9.

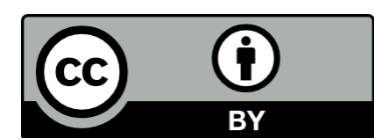

(C) 2022 by the authors. This article is an open access article distributed under the terms and conditions of the Creative Commons Attribution (CC BY) license (http://creativecommons.org/licenses/by/4.0/). 